\title{
A STUDY OF PREVALENCE OF INTESTINAL PROTOZOAN INFECTIONS AND ASSOCIATED RISK FACTORS AMONG THE SCHOOL CHILDREN OF ITAHARI, EASTERN REGION OF NEPAL
}

\author{
RB Sah ${ }^{1 *}$, IS Paudel ${ }^{1}$, R Baral $^{2}$, P Poudel $^{3}$, N Jha ${ }^{1}$ and PK Pokharel ${ }^{1}$ \\ ${ }^{1}$ School of Public Health and Community Medicine, ${ }^{2}$ Department of Microbiology, \\ ${ }^{3}$ Department of Pediatrics, BP Koirala Institute of Health Sciences, Dharan, Nepal \\ *Correspondence to : Dr Ram Bilakshan Sah, School of Public Health \& Community Medicne, B P Koirala Institute of Health Sciences, Dharan, Nepal.
}

Email:bilaksah@yahoo.com

\begin{abstract}
Intestinal parasites, notably the protozoa are among the most common infections of school age children where they cause morbidity in developing countries. The objective of the study was to measure the prevalence of intestinal protozoan infection and to identify risk factors associated with protozoan infection among the school children of Itahari.The cross sectional study was conducted in Grade VI, VII and VIII in schools of Itahari Municipality. Stratified random sampling method was applied to choose the schools and the study subjects. Semi-structured questionnaire was administered to the study subjects and microscopic examination of stool was done. The Chi-square test was used to measure the association of risk factors and intestinal protozoan infections.Overall intestinal protozoan infection was found to be 18.5 percent. Giardia lamblia was found high (10.5\%) in comparison to Entamoeba histolytica (8\%). Almost (18.4\%) of male and (18.6\%) of female were infected with protozoan parasites. The use of soap and water after defecation had lower prevalence of protozoan infections $(16 \%)$ than only use of water $(28.9 \%)$. The protozoan infection was significantly lower among having clean nail (6\%) in comparison to having not clean $(24.8 \%)$ respectively. We conclude that the prevalence of intestinal protozoan infection was found to be high in school children of Itahari and those having unhygienic skin, nail and clothes, and the habit of nail biting and thumb sucking was found to have significant relationship in the causation of intestinal protozoan infection.
\end{abstract}

Key Words: Prevalence, Risk factors, School children \& Intestinal protozoan infections

\section{INTRODUCTION}

Although intestinal parasites seem to raise much less interest than do AIDS and tuberculosis, they are a major public health problem in tropical regions. ${ }^{1}$ In 2002 , WHO estimated the number of people infected by digestive tract parasites at 3.5 billion and the number of people made ill by them at 450 million. ${ }^{2}$ Whereas much effort is being made toward a better comprehension of helminth epidemiology ${ }^{3}$, relatively few equivalent studies are done on intestinal protozoa. This is surprising, because intestinal amoebiasis caused by the protozoan Entamoeba histolytica is the third-greatest parasitic disease responsible for death in the world after malaria and schistosomiasis. ${ }^{4}$ It affects approximately 180 million people, of whom 40,000 to 110,000 die each year. ${ }^{5}$

Among important enteric protozoa, Giardia lamblia which is worldwide distribution and is common in warm moist climates. ${ }^{6}$ Giardiasis, caused by Giardia lamblia, is a frequent cause of diarrhea that can have a negative impact on growth and development of children ${ }^{8}$ and affects approximately 200 million people worldwide. ${ }^{9}$ Giardia lamblia is transmitted by the fecaloral route and direct person to person spread. In most of the cases it is associated with contaminated water with sewage material. ${ }^{10}$ Therefore this study was designed to measure the prevalence of intestinal protozoan infection and to identify risk factors associated with protozoan infection among the school children of Itahari.

\section{MATERIALS AND METHODS}

The cross sectional study was conducted from 15th Nov 2011 to 14th March 2012 in Grade VI, VII and VIII in Government and Private schools of Itahari Municipality. This research was based on random selection of the study area Itahari Municipality. Stratified random sampling method was applied to choose the schools and the study subjects. Out of total 47 schools in Itahari Municipality, 7 were Government (15\%) and 40 were Private schools (85\%). The sample was taken 200 school children aged 12-15 years. Out of 200, 15 percent (30) were taken from Government schools and 85 percent (170) were taken from Private schools on the basis of probability proportionate to sample size. Study subjects were enrolled till the required 
sample size was full filled.

Written permission was taken from each schools head and verbal consent was taken from each student. Students of Grade VI, VII and VIII of both sexes, who are available after three visits and willing to give verbal consents, are included in the study.

Semi-structured questionnaire was administered to the study subjects and microscopic examination of stool was done. In each visit more than 20 students were enrolled \& same number of plastic bottles was given for stool collection and collected next day morning. Microscopic examination of stool was done by preparing slide using Normal Saline and Lugol's Iodine to observe the ova of different protozoan parasites. First we used low power lens and afterwards the high power lens. Then we observed ova, cyst of protozoan parasites. ${ }^{11}$

The prevalence was calculated, Chi-square test was used to measure the association of risk factors and intestinal protozoan infection. The probability of occurrence by chance is significant if $\mathrm{P}<0.05$ with $95 \%$ Confidence Interval.

\section{RESULTS}

Table 1: Distribution of protozoan infection among study population

\begin{tabular}{|c|l|l|}
\hline Protozoan infection & Frequency & Percent \\
\hline Protozoa & & \\
Positive & 37 & 18.5 \\
Negative & 163 & 81.5 \\
\hline Name of protozoa & & \\
Entamoeba histolytica & 16 & 8.0 \\
Giardia Lamblia & 21 & 10.5 \\
\hline
\end{tabular}

Almost (18.5\%) of study population was infected with protozoan parasites. Giardia lamblia was seen high (10.5\%) in comparison to Entamoeba histolytica (8\%).

Table 2: Association between socio-demographic characteristics with protozoan infection

\begin{tabular}{|c|c|c|c|c|}
\hline Characteristics & Protozoa Positive & Protozoa negative & Total & P-value \\
\hline $\begin{array}{l}\text { Gender } \\
\text { Male } \\
\text { Female }\end{array}$ & $\begin{array}{l}19(18.4) \\
18(18.6)\end{array}$ & $\begin{array}{l}84(81.6) \\
79(81.4)\end{array}$ & $\begin{array}{c}103 \\
97\end{array}$ & 0.984 \\
\hline $\begin{array}{l}\text { Religion } \\
\text { Hindu } \\
\text { Others(Muslim, Buddhist, Christian) }\end{array}$ & $\begin{array}{c}33(18.2) \\
4(21.1)\end{array}$ & $\begin{array}{c}148(81.8) \\
15(78.9)\end{array}$ & $\begin{array}{c}181 \\
19\end{array}$ & 0.763 \\
\hline $\begin{array}{l}\text { Fathers Education } \\
\text { Below SLC } \\
\text { SLC \& above }\end{array}$ & $\begin{array}{l}13(25.5) \\
24(16.1)\end{array}$ & $\begin{array}{c}38(74.5) \\
125(83.9)\end{array}$ & $\begin{array}{c}51 \\
149\end{array}$ & 0.136 \\
\hline $\begin{array}{l}\text { Mothers Education } \\
\text { Below SLC } \\
\text { SLC \& above }\end{array}$ & $\begin{array}{l}26(22.0) \\
11(13.4)\end{array}$ & $\begin{array}{l}92(78.0) \\
71(86.6)\end{array}$ & $\begin{array}{c}118 \\
82\end{array}$ & 0.123 \\
\hline
\end{tabular}

Protozoan infections were seen almost similar between male and female but the difference was not significant. Protozoan infections were found to be insignificantly higher in school children whose father and mother had below SLC. 
Sah et al, Journal of Chitwan Medical College 2013; 3(3)

Table 3: Association between personal hygiene and food habit with protozoan infection

\begin{tabular}{|c|c|c|c|c|}
\hline Characteristics & Protozoa positive & Protozoa negative & Total & P-value \\
\hline $\begin{array}{l}\text { Source of drinking water at home } \\
\text { Tap } \\
\text { Tube well }\end{array}$ & $\begin{array}{l}17(13.5) \\
20(27.0)\end{array}$ & $\begin{array}{c}109(86.5) \\
54(73.0)\end{array}$ & $\begin{array}{c}126 \\
74\end{array}$ & 0.017 \\
\hline $\begin{array}{l}\text { Water treat at home } \\
\text { Yes } \\
\text { No }\end{array}$ & $\begin{array}{c}6(11.1) \\
31(21.2)\end{array}$ & $\begin{array}{c}48(88.9) \\
115(78.8)\end{array}$ & $\begin{array}{c}54 \\
146\end{array}$ & 0.102 \\
\hline $\begin{array}{l}\text { Hand wash before meal } \\
\text { Water only } \\
\text { Soap }\end{array}$ & $\begin{array}{c}35(20.8) \\
2(6.3\end{array}$ & $\begin{array}{c}133(79.2) \\
30(93.8)\end{array}$ & $\begin{array}{c}168 \\
32\end{array}$ & 0.052 \\
\hline $\begin{array}{l}\text { Hand wash after defecation } \\
\text { Soap } \\
\text { Water }\end{array}$ & $\begin{array}{l}26(16.0) \\
11(28.9)\end{array}$ & $\begin{array}{c}136(84.0) \\
27(71.1)\end{array}$ & $\begin{array}{c}162 \\
38\end{array}$ & 0.065 \\
\hline $\begin{array}{c}\text { Sandal wear } \\
\text { Yes } \\
\text { No }\end{array}$ & $\begin{array}{l}14(14.1) \\
23(22.8)\end{array}$ & $\begin{array}{l}85(85.9) \\
78(77.2)\end{array}$ & $\begin{array}{c}99 \\
101\end{array}$ & 0.116 \\
\hline $\begin{array}{ll}\text { Skin } & \\
& \text { Clean } \\
& \text { Not-clean } \\
\end{array}$ & $\begin{array}{c}5(7.1) \\
32(24.6) \\
\end{array}$ & $\begin{array}{l}65(92.9) \\
98(75.4)\end{array}$ & $\begin{array}{c}70 \\
130 \\
\end{array}$ & 0.002 \\
\hline $\begin{array}{ll}\text { Nail } & \\
& \text { Clean } \\
& \text { Unclean }\end{array}$ & $\begin{array}{c}4(6.0) \\
33(24.8)\end{array}$ & $\begin{array}{c}63(94.0) \\
100(75.2)\end{array}$ & $\begin{array}{c}67 \\
133\end{array}$ & 0.001 \\
\hline $\begin{array}{l}\text { Clothes } \\
\qquad \begin{array}{l}\text { Clean } \\
\text { Not-clean }\end{array}\end{array}$ & $\begin{array}{c}6(8.6) \\
31(23.8)\end{array}$ & $\begin{array}{l}64(91.4) \\
99(76.2)\end{array}$ & $\begin{array}{c}70 \\
130\end{array}$ & 0.008 \\
\hline $\begin{array}{l}\text { Habit of nail biting } \\
\text { Yes } \\
\text { No }\end{array}$ & $\begin{array}{l}19(27.5) \\
18(13.7)\end{array}$ & $\begin{array}{c}50(72.5) \\
113(86.3)\end{array}$ & $\begin{array}{c}69 \\
131 \\
\end{array}$ & 0.017 \\
\hline $\begin{array}{l}\text { Habit of thumb sucking } \\
\text { Yes } \\
\text { No }\end{array}$ & $\begin{array}{l}19(29.2) \\
18(13.3)\end{array}$ & $\begin{array}{c}46(70.8) \\
117(86.7)\end{array}$ & $\begin{array}{c}65 \\
135\end{array}$ & 0.007 \\
\hline $\begin{array}{l}\text { Food habit } \\
\text { Vegetarian } \\
\text { Non-vegetarian }\end{array}$ & $\begin{array}{c}9(36.0) \\
28(16.0)\end{array}$ & $\begin{array}{c}16(64.0) \\
147(84.0)\end{array}$ & $\begin{array}{c}25 \\
175\end{array}$ & 0.016 \\
\hline
\end{tabular}

The protozoan infection was significantly higher in children having unhygienic skin, nail and clothes, and habit of nail biting and thumbs sucking.

\section{DISCUSSION}

Globally, the neglected intestinal parasitic infections (IPIs) have been recognized as one of the most significant causes of illnesses. With an average prevalence rate of $50 \%$ in developed world, and almost $95 \%$ in developing countries, it is estimated that IPIs result in 450 million illnesses. ${ }^{12}$ These infections are ubiquitous with high prevalence among the poor and socioeconomically deprived communities where overcrowding, poor environmental sanitation, low level of education and lack of access to safe water are prevalent. ${ }^{13}$

The current findings indicated that the prevalence of intestinal protozoan infection was $18.5 \%$ which is lower in comparison to studies carried out by Farag $\mathrm{H}$ et al in Yemen $(53 \%)^{14}$, Mehraj $\mathrm{V}$ et al in Pakistan $(52 \%)^{13}$ and Akhter $\mathrm{J}$ et al in Saudi Arabia 
$(27.8 \%)^{15}$ respectively. This study showed the prevalence of Entamoeba histolytica (8\%) which is lower than studies conducted by Legesse $\mathrm{M}$ et al in Ethiopia $(24.4 \%)^{16}$ and Bisht D et al in Ghaziabad, India $(20.3 \%)^{17}$ respectively. The prevalence of Giardia lamblia in this study was $10.5 \%$ which is lower than studies conducted by New man RD et al in Brazil $(25 \%)^{18}$, Magambo et al in Sudan $(24.4 \%)^{19}$ and Ozelik et al in Turkey $(25 \%) .{ }^{20}$ Itahari is a comparatively developed town with only a small number of people working in the fields, the periodic campaign of anti-helminthic drug administration to the children and health education about hygiene and sanitation given by different NGO, INGO in school children could possibly explain the lower prevalence of protozoan infections seen in this study.

The infection rate of protozoa was similar between male (18.4\%) and female $(18.6 \%)$ but the difference was not significant. A study conducted By Ngui R et al in Malaysia also showed similar infection rate of protozoa between male $(73 \%)$ and female $(73.3 \%) .{ }^{21}$ This indicated that the gender may or may not play role in parasitosis depending on the region and other environmental or behavioral factors. Generally, the increased mobility of the male increases the risk of infection among them, while female have more soil contact during growing vegetables and eat raw vegetable with prepared food more often than males. In this study protozoan infection was insignificantly higher in children whose mothers had below SLC $(22 \%)$ than SLC and above $(13.4 \%)$. But a study conducted by Hussein TK et al in Iraq showed the infection rate was significantly associated with level of mothers education. ${ }^{22}$ The Relation between child health and mothers education is well known. Health indicators of children whose mothers education level is lowers are always worse. ${ }^{23}$

This study showed the infection rate of protozoa was higher in children who did not treat water before drinking (21.2\%) than those treat $(11.1 \%)$ but the difference was not significant. Similar studies conducted by Hussein TK et al in Iraq ${ }^{22}$ and Ngui R et al in Malaysia ${ }^{21}$ also showed the higher rate of infection among children drink untreated water than those drink treated water. This high prevalence may be due to contamination of municipal water supplies with human waste, poor quality of water, faulty of sewage line and insufficient level of chlorine. In this study the infection rate of protozoan parasites among hand washing with soap and water after defecation was lower (16\%) than only use water $(28.9 \%)$ but the difference was not significant. Similarly a study conducted by Tadesse $G$ in Ethiopia also showed insignificantly lower rate of protozoan infection among the children those washing hands with soap and water after defecation. ${ }^{24}$

This study showed the association of parasitic infection with sandal wearing habit insignificant but higher among children not wearing sandal $(22.8 \%)$ in comparison to sandal wear $(14.1 \%)$. But a study conducted by Tadesse G showed positive parasites significantly lower among sandal wear (3.9\%) as compared to not sandal wear (9.6\%).24 The positive protozoan infection among school children was significantly lower among having clean nail (6\%) in comparison to not clean $(24.8 \%)$ respectively.
The studies conducted by Wani SA et al in Gurez Valley of Jammu and Kashmir State, India ${ }^{25}$ and Tadesse G in Ethiopia ${ }^{24}$ also showed lower prevalence of intestinal parasites among the children those having clean nail in comparison to having not clean nail.

In this study the prevalence of intestinal protozoan parasites was found significantly higher among vegetarian group (36\%) than non vegetarian group (16\%). A similar study conducted by Rai SK et al in Nepal also showed vegetarians had higher parasitic infection rate as compared to their non-vegetarian counter parts. Consumption of unwashed fruits and vegetables appeared to be the source of infection among the vegetarians. ${ }^{26}$

Limitations of this study: Firstly, we conducted single stool examination for detection of intestinal protozoan infections, which could have underestimated the prevalence, as optimal laboratory diagnosis of intestinal parasitic infections requires the examination of at least three stool specimens collected over several days. ${ }^{27}$ Secondly, we cannot draw conclusions on the association of different factors with intestinal protozoan infections as this is a limitation in cross sectional study design.

\section{CONCLUSION}

The prevalence of intestinal protozoan infection was high among school children of Itahari. The prevalence of protozoan infestation was seen high among unhygienic skin, nail and clothes, habit of nail biting and thumbs sucking, and the vegetarian groups. Health education regarding hygienic practices in the school at primary levels can have substantial effect in prevention of intestinal protozoan parasites among the children.

\section{ACKNOWLEDGEMENT}

We would like to thank to School of Public Health and Community Medicine for approval of our research work. Our gratitude and sincere thank to all the participants of study from Schools of Itahari and teachers for their kind co-operation.

\section{REFERENCES}

1. Dianou D, Poda JN, Savadogo LG, Wango SP, Sombo B. Intestinal parasite infections in the Sourou hydroagricultural system zone of Burkina Faso. VertigO 2004; 5:3-10.

2. WHO. Burden of desease in disability-adjusted life years (DALYs) by cause, sex and mortality stratum in WHO regions. Geneva: WHO, 2001.

3. Lammie PJ, Fenwick A, Utzinger J. A blueprint for success: integration of neglected tropical disease control programmes. Trends Parasitol 2006; 22: 313-321.

4. Voigt H, Olivo JC, Sansonetti P, Guillen N. Myosin IB from Entamoeba histolytica is involved in phagocytosis of human erythrocytes. J Cell Sciences 1999;112:1191-1201.

5. WHO. News and activities. Entamoeba taxonomy. Bull World Health Organ 1997; 75: 291-293. 
6. Keating JP. Giardiasis. Text book of pediatric Infectiousdiseases, 4th ed. Philadelphia, WB Saunders 1998: 2400- 3.

7. Faye O, N'Dir O, Gaye O, Dieng TH, Bah IB. Giardiasis among child: Morbidity risk factors in Dakar urban environment. Med Afr Noire 1997; 44: 531-535.

8. Simsek Z, Zeyrek FY, Kurcer MA. Effect on Giardia infection on growth and psychomotor development of children aged 0-5 years. J Trop Pediatr 2004;50:90-93

9. Mineno T, Avery MA. Giardiasis: recent progress in chemotherapy and drug development. Curr Pharm Design 2003; 9: 841-855.

10. WHO. Interdisciplinary consultation on development of national food safety program. WHO 1992; 19: 1- 2 .

11. Godkar PB, Godkar DP. Microscopic examination of stool specimen. Text book of Medical Laboratory Technology. 2nd edition, 2003, page 937-952.

12. WHO. Control of Tropical Diseases. Geneva: World Health Organisation, 1998.

13. Mehraj V, Hatcher J, Akhtar S, Rafique G, Beg MA. Prevalence and factors associated with intestinal parasitic infection among children in an urban slum of Karachi, 2008. PLoS ONE 3: e3680. Doi:10.1371/journal.pone.0003680.

14. Farag H. Intestinal parasitosis in the population of the Yemen Arab Republic. Tropical and Geographical Medicine 1985; 37: 29-31.

15. Akhter J, Markley Burdette J, Hussain Q. Aetiology of gastroenteritis at a major referral centre in Saudi Arabia. Journal of International Medical Research 1994; 22: 47-54.

16. Legesse M, Erko B. Zoonotic intestinal parasites in Papio anubis (baboon) and Cercopithecus aethiops (vervet) from four localities in Ethiopia. Acta Tropica 2004; 90: 231-236.

17. Bisht D, Verma AK, Bharadwaj HHD. Intestinal parasitic infestation among children in a semi-urban Indian population.Tropical parasitology 2011; 1(2): 104-107.
18. New man RD, Moore SR, Lima AM. A longitudinal study of Giardia lamblia in north-east Brazilian children. Trop Med Int Health 2001; 6: 624-634.

19. Magambo Jk, Zeyhle E, Wachira TM. Prevalence of intestinal parasite among children in southern Sudan. East Afr Med J 1998; 75: 383-90.

20. Ozelik S, poyraz O, Saygi G, Ozturkcan S. prevalence of intestinal parasite in children of the orphan-age in Sivas, Turkey. Ind pediatr 1995; 32: $230-232$.

21. Ngui R, Ishak S, Chuen CS, Mahmud R, Lim YAL. Prevalence and Risk Factors of Intestinal Parasitism in Rural and Remote West Malaysia, 2011. PLoS Negl Trop Dis 5(3): e974. doi:10.1371/journal.pntd.0000974

22. Hussein TK. Prevalence and related risk factors for Giardia lamblia infection among children with acute diarrhoea in Thi-Qar, Southern Iraq. Thi-Qar Medical Journal 2010; 4 (4): 68-74.

23. Hacettepe university institute of population studies: Turkish demographic health survey (TDHS) Ankara, 1998.

24. Tadesse G. The prevalence of intestinal helminthes infections and associated risk factors among school children in Babile town, eastern Ethiopia. Ethiop J Health Dev 2005; 19:140-7.

25. Wani SA, Ahmad F, Zargar SA, Amin A, Dar ZA, Dar PA. Intestinal helminthiasis in children of Gurez valley of Jammu and Kashmir state, India. J Glob Infect Dis 2010; 2: 91-4.

26. Rai SK, Gurung R, Saiju R, Bajracharya L, Rai N, Gurung $\mathrm{K}$ et al. Intestinal parasitosis among subjects undergoing cataract surgery at the eye camps in rural hilly areas of Nepal. Nepal Med Coll J 2008; 10 (2): 100-103.

27. Rashid MK, Joshi M, Joshi HS, Fatemi K. Prevalence of Intestinal Parasites among School Going Children in Bareilly District. NJIRM 2011; 2 (1):35-37. 